\title{
Unmaking the Male Body: The Politics of Masculinity in The Long Dream
}

\begin{abstract}
How you construct your identity is predicated on how you construct desire and how you conceive of death: desire for recognition; quest for visibility; the sense of being acknowledged; a deep desire for association-what Edward Said would call affiliation. ... But identity also has to do with death. We can't talk about identity without talking about death. That's what [a gay Puerto Rican] brother named Julio Rivera had to come to terms with: the fact that his identity had been constructed in such a way that xenophobes would put him to death. Or brother Youssef Hawkins in Bensonhurst. Or brother Yankel Rosenbaum in Crown Heights. Persons who construct their identities and desires often do it in such a way that they're willing to die for it-soldiers in the Middle East, for example-or under a national identity, that they're willing to kill others. And the rampant sexual violence in the lives of thousands of women who are attacked by men caught up in vicious patriarchal identities-this speaks to what we're talking about. (Cornel West 163)
\end{abstract}

\section{L}

ess than a quarter of the way into Richard Wright's The

Long Dream, readers are faced with the stark image of a lifeless body, and a passage which describes a man's torture and castration for transgressing the cultural taboo of miscegenation. Here Wright presents a narrative of pain so absolute that it would be far simpler to pass quickly over the description than to linger on it. But the novel bluntly renders the image of Chris Sims as he is laid out in the basement of Tyree Tucker's funeral home, where his body is "laid bare," "scrutinized," and "explored" during the performance of a makeshift autopsy. The incident is key to Wright's African American Bildungsroman, where the negative lesson of Chris Sims's body serves to deconstruct-or "unmake"- the evolving masculine identity of the novel's protagonist, Rex "Fishbelly" Tucker. For Wright, the black male body is the exemplary site of the contest, disruption, and emergence of African American identity in what might be called his highly personal vision of the South. ${ }^{1}$

Before the doctor begins to narrate the autopsy, Wright describes Tyree and Fish-father and son-standing side-by-side, "gazing bleak-eyed at the body of Chris in a silence so agonizing that Fishbelly wanted to scream" (75). This painful silence seems to mirror the unspeakable and now-distant experience of Chris's pain. Yet Fish's desire to scream seems even further intensified due to the fact that the image of Chris's agony can elicit at best only inarticulate screams, not language. Elaine Scarry has offered one version of this relationship between language and acts of torture, focusing particularly on those cases in which pain is inflicted as a flagrant display of a regime's political authority. In The Body in Pain, she has suggested that "torture is such an extreme event that it seems inappropriate to generalize from it to anything
Jeffrey Geiger teaches American studies and film at the University of Essex, United Kingdom. 
else or from anything else to it. Its immorality is so absolute and the pain it brings so real that there is a reluctance to place it in conversation by the side of other subjects" (60). Rather than turn away from such "unspeakable" acts of violence, then, my investigation will turn its attention toward them, as Wright's work itself does, with the hope that, by directing the critical lens toward events elided from, and resistant to, conventional discourse, this analysis might itself suggest different ways of looking at the day-to-day construction of racial difference as threat, to which lynching has been an extreme response.

With Scarry's meditations on the phenomenology of the body in pain serving as a subtext, I hope to show that the silences and privations of language that accompany The Long Dream's most painful scene are grounded in a coherent theory of language under the physical and political pressure of pain. Lynching is an act that negates the signifying power of language, thereby erasing one of the formative features of identity: In doing so the torturers strive to fill the void left in the targeted community with their own dangerously unbalanced discourse of race and sexuality.

Furthermore, by specifically targeting the visible physiological and cultural signs of gender and sexuality, lynching-in Wright's view-powerfully reconfigures the relationship of self to body for the African American male. The Long Dream, as a result, frequently demonstrates a peculiar slippage between traditionally fixed masculine and feminine roles, suggesting that Wright perceived deeper links between the development of African American masculine identity and the actual and psychic castration prominent in cases of lynching: a spectacle of white hysterical violence that targets not only black social autonomy but also the visible signifiers of masculine identity.
A body effaced, reduced to dust and thrown to the winds, a body destroyed piece by piece by the infinite power of the sovereign constituted not only the ideal, but the real limit of punishment. (Michel Foucault 50)

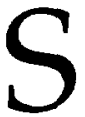
carry's discussion of human pain is immediately located in the political; not only is physical pain "unspeakable," but its very resistance to language serves to reinforce certain power inequalities: One cannot "speak out," or even "speak about," unutterable pain. The situation is not easily rectified: Overcoming this aporia is more complicated than merely developing "tact" or constructing a basic vocabulary for articulating pain, because the fact of "intense pain," as Scarry puts it, "is world destroying" (29). Pain is not only resistant to language, but actively destroys it. Pain forces an immediate reversion to a state anterior to language, to "the sounds and cries a human being makes before language is learned" (4). The victim of torture is thus subject to a repositioning of cultural meanings that are governed by language. Pain is channeled and reconverted into political power: The victim's familiar world is destroyed, while being simultaneously remade into an image of the dominant regime's political and cultural constructs.

For Wright, lynching is similarly figured as a disciplining spectacle: a political tool for circumscribing racial and psychosexual identities that deconstructs and strives to reconfigure African American subjectivity into its own convoluted image. Though in many ways lynching bears certain features in common with the spectacle of the scaffold discussed by Michel Foucault (51), it is significant that, unlike state punishment, no divine sovereign or written law sanctions the arbitrary and ambiguous act of lynching. Trudier Harris has suggested that lynching departs from the concept of torture as punishment for legal transgression due in large part to this very 
arbitrariness, which helps drive the event below language: Acts that are difficult to report become even more difficult to explain. For Harris, the fact of lynching ruptures the veneer of "civilized" U.S. culture: She sees lynching as a return to the more distant, ritual taboos of "undeveloped societies," suggesting that the lynch mob acts out a ceremony similar to a primitive ritual of sacrifice in which evil is symbolically expunged for the survival of the greater society. For Foucault, state torture similarly forms part of a more precise ritual that serves as a sign of power: Torture intends to "brand the victim with infamy," inscribing scars on the body as signs that cannot be effaced, so that "men will remember public exhibition ... torture and pain duly observed" (34). Yet the lynch mob acts without understanding the significance or purpose of its actions. Harris writes, "The crowd destroys without fully understanding why, and there is no release for any in the end-no rain falls, no bountiful harvest is forthcoming" (13). ${ }^{2}$

Even if an explanation of the phenomenon of lynching were within Richard Wright's ability as a writer, he concentrates instead on reporting rather than explaining, and on documenting lynching's effects on the targeted community. ${ }^{3}$ The cultural residue of the ambiguous act is thus not, for Wright, an abstract idea or public sign to be interpreted by the masses, but an experience of palpable pain, felt through a community of witnesses. Pain in The Long Dream becomes, as Harris has written of racial memory in general, a living thing ${ }_{t}$ just as pain in Wright's work overall appears as a primary component of this racial memory.

Wright introduced the lynching image in "Between the World and Me," a long poem that appeared in The Partisan Review in 1935 and describes the chain of events that would reappear in slightly different form at the center of The Long Dream. For Harris, lynching in the early poem "serves as a model for the literal and metaphorical lynchings which occur throughout the corpus of Wright's work as well as a model for discussion of the psychology of repression used historically against Blacks" (105). "Between the World and $\mathrm{Me}^{\prime \prime}$ thus uncovers the very essence of pathos, in the Greek sense of suffering and deep feeling, conveying the acuteness of the felt experience of torture by reading it through an intense, sympathetic act of witnessing. Walking in the woods, the speaker stumbles upon the scene of a lynching, with "white bones slumbering forgottenly upon a / cushion of gray ashes" (18). At first the speaker reacts as a remote bystander, feeling "a cold pity for / the life that was gone." But soon the scene shifts from passive observation to active engaging:

The dry bones stirred, rattled, lifted, melting themselves into my bones.

The gray ashes formed flesh firm and black, entering into my flesh .... (18)

As Harris observes, the speaker "then takes us to a higher level of imagination in transcending time and space and recreating with his own body what happened to the dead man some time before" (102).

Wright represents the felt experience of pain by registering its effects on the body of his speaker, moving from exteriority and distance ("white bones") to interiority and knowing ("flesh firm and black"), suggesting that pain's effects might transgress and transcend the limits of the flesh. The speaker's re-experience soon moves beyond the body to center on the rupturing of language and voice: "My voice was drowned in the roar of their voices," the speaker observes; "I moaned in my agony." Intense pain always raises the question of the relation of body to voice: It places its victims beyond the threshold of language. Harris convincingly argues that Wright, in moving from passive observation to active experience of the crime-from starting with random details to later arriving at a calculated 
and systematic ordering of eventstransforms a history of African American victimization into the "substance of art" (104). Lynching thus becomes a common image across nearly all of his texts - "the center of his aesthetic for the remainder of his career" (97). But underlying this process is the question of how the writer returns language to a space that kills the voice, without obliterating or minimizing the human experience of pain itself: How does the writer embody pain in the text? What "Between the World and $\mathrm{Me}^{\prime}$ does not elaborate upon is the very manner in which the poem's speaker brings the hidden, unspeakable crime into language. The Long Dream attempts to present a clearer image of both this process of reconstructive pathos, and further works to underscore the effects of lynching's actual and symbolic violence on an emerging African American masculine identity.

The physical pain lof torture] is so incontestably real that it seems to confer its quality of "incontestable reality" on that power that has brought it into being. It is, of course, precisely because the reality of that power is so highly contestable, the regime so unstable, that torture is being used. (Elaine Scarry 27)

0 ignificantly, Wright seems incapable of, or unwilling to, present the unspeakable act of lynching in The Long Dream, but he underscores its representation in the text by reconstructing the event after-the-fact, as the figure of Doctor Bruce narrates the incidents over Chris's lifeless body. This act of narration, on the one hand, attests to the invisibility of such crimes and the problems involved in reproducing them while, on the other hand, it comments on the task of the writer, who-like Doctor Bruce performing the autopsy-must recount the details of an event that has become erased from legal memory, that never really happened. ${ }^{4}$ Within dominant discourse, Chris's murder is in essence already an extralegal fiction. Wright is thus clear that the scene he describes has no official author or narrator: Indeed, Tyree asserts that " the inquest'll say that he was killed "resisting arrest" ," (79). Because Chris can no longer speak, his experience is brought into language by a figure who must simultaneously translate and interpret the text of the crime as it is inscribed in his wounds. At first, the speaking of Chris's agony promises to perform a curative function: If nothing else, it will alleviate the agony of a prolonged silence. Opposed to the violent image of Chris's body, with his "bloated head and torso," Dr. Bruce's voice is measured, even businesslike, and he manages to elicit a languagehowever clinical - that restores a certain perspective and order to the events. Bruce begins, " 'They must've killed him right after lunch.... Rigor mortis has set in,' " and sets up the macabre convergence of the ordinary and the extraordinary that defines acts of torture by placing the calm, thoroughly domestic routine of afternoon lunch in narrative collusion with lynching. The doctor's treatment of the corpse is further described as "delicate," a word which stands in stark contrast to the lynch mob's treatment of Chris as a living, sentient being. Leaning over the unrecognizable face, the doctor observes the "extensive lacerations":

\footnotetext{
"The right ear's missing," Dr. Bruce pointed out calmly, indicating a dark blot of blood on the side of the head. "Seems that it was scraped, sheared off. Could have been eaten away by the friction of asphalt against the side
} 
of the head. No doubt they tied him to the back of a car and dragged him through the streets." (76)

Bruce's measured, clinical approach is not, paradoxically, a distancing strategy, but a necessary mechanism for bringing the event into language and helping the body to testify; his approach is suggestive, even sensitive. The doctor's "remaking" of the last moments of Chris's life, however horrific, returns a semblance of continuity and cause and effect to an act of hysterical violence. But even with these efforts, the attempt to articulate pain reveals the limits of linguistic communication itself. When Tyree asks about the degree to which Chris felt the pain--whether he suffered or was killed quickly-Bruce is left to confess his limitations:

\begin{abstract}
"Tyree, we've been tortured by whites for three hundred years, and nobody has learned anything from it. ... they tortured us for their own, special morbid reasons. Tyree, you just suggested something that, as a doctor, I ought to know, and I don't." (77)
\end{abstract}

The absolute privacy of the victim's pain is something we cannot-and perhaps should not have to-enter. While a doctor is employed to "read" a patient's pain, and from the descriptive clues to diagnose the cause, for the doctor-turned-coroner the felt experience of Chris's pain is beyond articulation: It is not possible to provide an external image of his interior trauma. Likewise, the doctor attempts to locate the agenda of the white torturers, but is left at a loss. He can only conclude, significantly, that both sides "suffer" (78).

The lynch mob has not only robbed Chris of life, but even of "the semblance of the human." " His very humanity is displaced, and he becomes an amalgam of definite and indefinite articles: "the mouth, lined with stumps of broken teeth . . an irregular, black cavity bordered by shredded tissue that had once been lips. The swollen eyes permitted slits of irises to show ..." (76; my italics). As the doctor proceeds with an inventory of physical violence and violation, the loss of Chris's humanity becomes a metaphor for the displacement of human and cultural relations in the black community. This shift entails the loss of Chris as a "him," to be replaced by an "it," even erasing the linguistic markers that determine him as a gendered being.

This aspect of Chris's loss soon becomes even more explicit when, in the final moments of the autopsy, Bruce reveals the definitive act of Chris's castration by the mob: The doctor "rolled the corpse upon its back and carefully parted the thighs. "The genitalia are gone' the doctor intoned" (78). Wright's language underscores the doctor's discovery by blurring gender oppositions-the doctor's parting of the thighs appears to render the corpse feminine, while the loss of genitalia provides a metaphor for the displacement of masculine identity at the hands of a violent mob, further inscribing the logic of "rape" into the torture. As Harris argues, lynching performs an "ironic reversal" of the alleged sexual crime by evolving into a form of communal rape:

From one perspective, then, there is an ironic reversal in that there is a communal rape of the black man by the crowd which executes him. They violate him by exposing the most private parts of his body and by forcing him, finally, into ultimate submission to them. Comparable to sexual snuff films...the lynched black man becomes a source of sexual pleasure to those who kill him. (23)

Like the act of rape, Chris's lynching blurs the boundaries of the psychosexual and the political, transforming the personal experience of pain into a fraudulent assertion of legitimate authority while evading social definition in the white community as the anti-human act or the grotesque drama that it actually is.

Fishbelly's father paradoxically expresses relief that Chris Sims has been killed: " 'It's a good thing he's dead. ... Lissen: when them white folks get all roused ... when they git 
all mixed up in their minds about their women-when that happens they want blood! ... And there can't be no peace in this town 'less they get their blood!' " (71). Tyree's fatalism is grounded in actual experience, and leads him to take on the responsibility of conferring the codes of lynch law to his son. The sight of Chris's mutilated body, Tyree thinks, will instill in Fish the fear of miscegenation and white reprisal. As Earl V. Bryant has observed, the witnessing of Chris's brutalized body is part of an essential rite of passage, an element of "Fish's sexual initiation," which is "an absolute prerequisite for his survival in the white world" (57). Yet Fish perceives a faint irony in Tyree's actions. His father is an undertaker, literally a "body snatcher," whose business is explicitly concerned with transforming black bodies-even Chris's - into money. Legend has it that Tyree once even went so far as to paint a dead body black, when it had become too "light" colored after being drained of blood and embalmed (50). This effort to construct a simulacrum of normal (and even, perhaps, "white") life out of the dehumanized body is also reflected in Tyree's silent trade in living bodies-managing brothels in collusion with white law enforcement, where female bodies are sold in exchange for his own semblance of comfortable bourgeois family life. Tyree extends the white project of commodifying the black body, and in so doing threatens to extend the legacy of slavery and of slave mentality to his son.

Fish, who at this point knows little of his father's activities, silently criticizes Tyree for not "resisting" the whims of white law, and momentarily comes to see in Tyree all of the emasculated, self-hating qualities of a black man living under a white-constructed "reality." Yet Fish will also observe, soon after, that his father is already powerless to fight the white world: "He knew in a confused way that no white man would ever need to threaten Tyree with castration; Tyree was already castrated" (151). As Harris bluntly puts it, Tyree is a eunuch; he has actually surrendered masculinity for a certain amount of circumscribed power among white leaders. Stephen Best has recently read this exchange in the context of Wright's Black Boy as the intersection of lynch law (or the law of abuse and threats of bodily harm) and family law (the law of "the Southern way of life," in which people occupy a hierarchically determined "place"). Family law becomes the heuristic tool of a lynch law that masquerades as divine justice: "Family law is the site where hegemony is made tangible, the domain where blacks give over their rights to agency" (115). This coefficiency of lynch law and family law is vividly seen as Tyree denies his own rights to agency and expresses his acceptance of Chris's murder as an act of Christlike martyrdom which will perpetuate black survival in a white world. " "Chris died for us,' " he says, effectively denying the political dynamics of racially motivated torture and replacing them with an image of divine justice. Tyree sees no choice but to sanction the sacrificing of a black body to white violence, as long as it does not cross the lines of his own strictly bourgeois and patriarchal concepts of family affiliation. Fish, however, finds it impossible to "read" Chris's lynching in terms of self-preservation or exchange, and his father's lesson takes an unexpected turn, where the image of Chris's body enacts a strange form of bodily possession that returns Wright's narrative to the site of intense identification described in "Between the World and Me."

He was a long, taut piece of rubber which a thousand white hands had stretched to the snapping point, and when he snapped it was rape. But it was rape when he cried out in hate deep in his heart as he felt the strain of living day by day. That, too, was rape. (Richard Wright, Native Son 214) 
$\mathrm{F}$ ishbelly is twelve when he witnesses the end result of Chris's torture. Chris had constituted a role model, a figure who at one time threatened to eclipse the masculine example offered by his father. In Chris there had been an element of independence and disregard for the conventions of Southern racial hierarchy, especially in his open and liberated sexual expressiveness. It was Chris who straightforwardly explained the mysteries of heterosexuality to Fish, after discovering Fish using a condom as a toy. But now the traumatic sight of Chris's mutilated body becomes a touchstone for scenes from Fish's own developing sexual identity. As Chris's body lies on the embalming table of Tyree's funeral home, the primal scene Fishbelly witnessed as a young child between his father and a client is recalled as Chris's mother (soon to be seduced by Tyree) is led to the same back bedroom: "Fishbelly trembled as he recalled that room and the time he stood terrified in the darkness while a thundering locomotive with two red eyes gleaming had trampled amid harsh breathing the body of a black woman" (76). The figure of Chris's murdered body re-opens the trauma of the primal scene, but here submits black male sexuality to threats of violence, and links it to the ultimate designifying power of death. Though the earlier scene was safely enacted outside the taboo of miscegenation, here it becomes explicitly connected to overarching and hierarchical forces of regulation and prohibition: Almost any active expression of black male desire runs the danger of retribution and even annihilation. The vivid memory of Tyree's sexual prowess thus explicitly merges with the sight of Chris's dead body:

Fishbelly realizes "that must have been what Chris was doing when the white folks had surprised him with the white woman" (76). Fish's voyeuristic witnessing of Chris's obscenely prone and exposed body immediately enters the mythic imaginary, condensing the lessons of a sexual education Fish has gained so far only through other similarly voyeuristic encounters.

Fishbelly's shift from identifying with the living Chris to seeing his own emerging masculine identity mirrored in the now-dead body culminates in the doctor's description of the final moments of the lynching: "The doctor ... indicated a rupture through which a blob of pearly intestine gleamed. ' $\mathrm{I}$ 'd guess,' Dr. Bruce spoke haltingly, impersonally, 'that a kick did that' " (78). Bruce's "impersonal" message is, however, as clearly aimed at Fishbelly as the kick itself was aimed at Chris's torso. As in "Between the World and $\mathrm{Me}$," a connection is made between victim and witness on the level of felt experience, yet here the full complexity of the moment of intense, worlddestroying pathos as personal and collective memory is brought closer to the text's surface. Chris's ruptured body immediately recalls Fishbelly's own naming in the opening paragraphs of the book, a naming that was drawn from another image of the exposed interior of the body: "a bit of sticky fish entrail" (6).

At the beginning of the novel, Fish is known by the (explicitly oedipal) name of Rex, but is nicknamed for a game he plays with his father-blowing up fish bladders into balloons, which he insists are "bellies" after recalling "a dim image" of a neighbor, who "had a baby and her belly had been big, big like these balloons." He shows the game to his friends, still calling the bladder-balloons "bellies," though his friends know better. They tease Rex for his ignorance by calling him Fishbelly, and he runs home "crying, stung with humiliation" (7). The traumatic scene of Fish's (re)naming, an imposition of what Orlando Patterson has called "the verbal sign of [a man's] whole identity, his being-inthe-world as a distinct person" (54), soon recedes from his memory, and he comes to accept his name and repress its origins. Furthermore, the scene warns that any neat-not to mention "normal" - oedipal readings of Rex's 
upbringing within the conventional family are futile, and are bound to be confounded and distorted by the record of his experiences growing up in the South.

True to the shifting, oneiric logic of The Long Dream, seemingly disconnected events condense, and are displaced onto other figures and images in a vain attempt to reorder and make sense out of the chaos of experience and an emergent consciousness. As the autopsy ensues, the scene of Fish's naming, his sexual education through both voyeuristic encounters and Chris's lessons, and the dead figure of Chris himself all converge in a moment that is to Fish both disorienting and transfiguring. In an instant, Fishbelly's own body is directly mirrored, through a process of projection and displacement, in the scene of torture and castration signified by Chris's wounds. Fish's body is systematically and symbolically deconstructed through witnessing the dissection of another body's discrete parts: "Fishbelly saw a dark, coagulated blot in a gaping hole between the thighs and, with a defensive reflex, he lowered his hand nervously to his groin" (78).

Wright's strategy of positioning the image of castration near the end of the autopsy serves as a climactic moment in the reconstruction of Chris's torture, and seems to imply that a racist discourse is capable not only of violently robbing the black body of cultural referentiality but also of wielding a power that forcefully resignifies black masculinity at every level: physical, social, and psychological. As the narrative of Chris's mutilation unfolds, Fish's tentatively constructed world is simultaneously unmade, and the positive sexual independence and defiance that Chris might have signified is replaced by a body that is no longer whole, but corrupted beyond recognition. Chris's body is now an empty signifier: in Scarry's terms, emptied of cultural content. As Walter Benjamin too has suggested in his own meditation on the signifying power of the figure of death, "Death digs most deeply the jagged line of demarcation between physical nature and significance" (166). A few hours before, Chris's complete body might have determined a distinct identity, but his exposed blood and bones do not now fall into a pattern that allows for positive identification. Only alive could he control the referential direction of his body, and only alive could he determine the ideas and beliefs that would be substantiated by his embodied presence. The open cavern of the wound-Chris's opened body, that Fish now quite graphically recognizes as his own-is empty of reference, open to a repositioning of cultural content determined by the fraudulent authority that took his life. Wright's South is thus one in which hegemonic racist practices strive to normalize "whiteness" and denature "blackness" at the ground level-that of the body. Through actual and symbolic violence, emasculation, and even rape, the rule of lynch law ultimately appropriates and reconfigures the relationship of self to body-a relationship which governs the construction of a black masculine self.

Inevitably, the image of Chris's body comes to bear upon another body that Fishbelly is forced to contemplate in the space of that evening - that of his father. Immediately after the autopsy scene, Wright notes that Fish
held toward his father nameless hatred; yet, at the same time, he felt more dependent upon him. He looked at the body slumped in the chair, at the black hand gripping the bottle, and he sensed that that deceptively lolling posture was hiding fear, restless scheming. A heavy sigh reached his ears; yes, Mrs. Sims was waking up in the guest room and he knew with swift instinct that his father was brooding rapaciously over the body of the moth- er of dead Chris. (79-80)

This passage is unlike earlier descriptions of Tyree. Here he is no longer "father," but a fragmented, degendered "it," a dismembered hand gripping a bottle, with skin vividly and sig- 
nificantly black. Likewise, Mrs. Simsalready so closely associated with her dead son-is now described in jarring syntax as, "the body of the mother of dead Chris." To Fishbelly, black bodies are systematically transformed into objectified "its": They are "made" or "unmade" according to the tenets of dominant (white) reason and desire. Chris's torturers have replaced the figure of the father with a body empty of reference, and have further caused Fish to believe that the black body is desexualized, passive unless it has access to a white discourse of sexuality and power, specifically embodied by the forbidden white woman. Thus, in spite of Fish's early inclinations, sexual relations with white women come to symbolize the essence of power and sexual potency. The world of black people becomes increasingly, to Fishbelly, a world of objectified black bodies: a sexual economy that functions only under the rubric of dominant distributions of power.

Fish's emerging masculinity is thus systematically unmade in terms of a positive racial or sexual identity, for it is formed within an arena of white power which circumscribes entrance into the social world by persistently threatening the black male subject with total erasure and indeterminacy.

Fearing the white woman, dismissive of the black woman, Fish is led away from any values that might have been reinforced in a coherent and autonomous community to internalize the oppositional and contradictory values of a Southern (white) hierarchy. The advantage that the white power hierarchy holds in keeping this system intact is primarily economic, but when this fails it swiftly calls upon the power to injure, and the incontestable fact of physical pain.

Eager to re-occupy a symbolic place in Fish's masculine development, now left vacant by Chris's death, Tyree stands behind his son in the autopsy room. Yet rather than exemplifying an identity based upon the full possession of his own embodied desires, Tyree denies the possibility of a full integration of desire and physical embodiment, offering instead a figure of compromise. This compromise is manifested in Tyree's physical make-up, which is dramatically transformed in the presence of any white threat. He can become "a woman with ten children telling her husband he could never leave her" (263), or even "something obscene" - a mistress who "purrs" to the white antagonist, using every tactic to cajole and gain favor (265). Tyree's form of drag, rather than presenting an alternative to Chris's fate, merely echoes it. Thus Wright's image of the father-who crosses gender boundaries and threatens to disrupt the coherence of a masculine identityevokes, like Chris, the figure of death. Tyree's wide grin and stooped posture quite graphically recall the death's head of tragic drama described by Benjamin (166), with its open mouth and paradoxically grinning rows of teeth.

Throughout much of the novel Fish works to separate the real from the dissimulating Tyree, and Fish himself even attempts to take his father's place, acting the role of the cheerful, emasculated black man. Trapped in this world of objectified black bodies and alien identities, Fish observes late in the novel that he is expected be "merely a face, a voice, a sexless animal" (388). It is not a role he can easily maintain, as his father once did. Even Cantley, the corrupt chief of police who had an illicit partnership with Fish's father, does$n$ 't feel he "knows" Fish like he "knew" Tyree: Fishbelly is " one of these new kind of niggers" " (365), unable to hide the impossible mixture of desire and hatred he feels toward those white figures who claim to own the Law.

By the end of the novel, Fish is still unresolved, remaining psychically suspended between the two worlds of Chris and his father-the former suggesting a model in which the enacting of masculine desire outside the confines of white power hierarchies will end in death, the latter suggesting a 
perpetual emasculation and what

Orlando Patterson has called the "social death" of slavery's legacy. The end of the novel, which finds Fish leaving Mississippi on a plane for France, presents Fish's flight on one level as "running away" from the realities of the South, perhaps to enter into another long dream, but on another leveland for the first time in his life-his body is literally released from the pull of gravity, and from the constitutive identities of home and place. If the fixing of masculine identity, like that of race, is a prevailing social fiction, perhaps Fish's newfound and transgressive mobility on the very level of the body will ultimately translate into a mobile and emergent understanding of his own masculine self.

Notes $\quad 1.1$ call Wright's vision "highly personal" for a number reasons, chiefly as a way of acknowledging the negative critical reception of the novel in 1958, which focused on Wright's exile in Paris and labeled the novel "out of touch" with contemporary changes in the South. As Margaret Walker has observed. Wright "could not envision a black world whirling into revolutionary action. He saw all black people as supine, apathetic, and unconscious as they were in the 1920 s and '30s" (304). Yoshinobu Hakutani has recently addressed the mixed reception of The Long Dream, arguing that a reassessment of Wright's achievement would need to focus less on the social accuracy of his account and more on his efforts to construct a "unique discourse" to express "what he actually felt as a black youth growing up in the deep South" (268). In essence, Wright's novel acknowledges the deeply contradictory nature of witnessing, in which factual events are by necessity filtered through cultural and subjective discourses.

2. In this essay I draw liberally from three scholars: Michel Foucault, Elaine Scarry, and Trudier Harris, all of whom have commented extensively on the social significance of torture. Interestingly, Foucault's analysis of torture as a political and cultural disciplining strategy never engages the ways that his theories might overlap with a racial discourse, or the spectacle of the lynch mob. Indeed, he suggests that such spectacles died out after 1800, though it might be argued that these entertainments merely moved underground. Neither Scarry nor Harris directly engages Foucault's ideas in their studies.

3. Wright is rarely read as for the theoretically complex, suggestive power of his images: More frequently critics have focused on the "positivism" of his prose, and the themes of his texts are seen as thinly veiled social documentary. According to Henry Louis Gates, Wright saw fiction "not as a model of reality but as a literal report of the real" (184). Yet, like some key moments in Native Son, The Long Dream, with its reliance on figurative language, dream imagery, and symbolic repetition, was clearly an attempt to move beyond the positivistic confines of the naturalism with which Wright had become associated. Writing on Native Son. Wimal Dissanayake argues that Wright's prose fails to become revolutionary because it is unable to "dislodge [an] existing discourse" inscribed by power Dissanayake draws on a gesture from Foucault, where the term " 'socialization,' . . . a common enough and innocent enough term in contemporary parlance," is linked to the expression "the penetrating of bodies." Such a gesture, Dissanayake argues, produces the rhetorical tropes in Foucault's text that serve to dislodge prevailing discursive practices, in this case by systematically linking violence to a term that has lost much of its implicitly disruptive meaning. Yet it might be said that in reading the text of ritual mob violence inscribed on the body of a young black man, Wright's own writing defies an existing code of power that circumscribes the articulation of such horrific acts.

Furthermore. Wright's deceptively positivistic prose strives to embody tropes and figures that encode the protagonist's "socialization" as, literally and figuratively, "the penetrating of bodies."

4. According to Margaret Walker in Richard Wright: Deamonic Genius, during and after Reconstruction, "Iynching and mob rule became an accepted part of the social order of Adams County [Wright's birthplace], throughout Mississippi, the South, and the rest of the United States [although] white residents of [Adams County] who were questioned by white interrogators denied that black people were regularly lynched in Adams County: 'there hasn't been a lynching here in Adarns County for seventy-five years' " (15-16). 
Benjamin, Walter. The Origin of the German Tragic Drama. 1928. Trans. John Osborne. New York: Verso, 1977

Best, Stephen Michael. " 'Stand By Your Man': Richard Wright, Lynch Pedagogy, and Rethinking Black Male Agency." Representing Black Men. Ed. Marcellus Blount and George P. Cunningham. New York: Routledge, 1996. 111-30.

Bryant, Earl V. "Sexual Initiation and Survival in Richard Wright's The Long Dream." Southern Quarterly 21.3 (1983): 57-66.

Dissanayake, Wimal. "Richard Wright: View from the Third World." Callaloo 9 (1986): 481-90.

Foucault, Michei. Discipline and Punish: The Birth of the Prison. Trans. Alan Sheridan. New York:

Random, 1977.

Gates, Henry Louis. The Signifying Monkey. Oxford: Oxford UP, 1988.

Hakutani, Yoshinobu. "Richard Wright's The Long Dream as Racial and Sexual Discourse." African American Review 30 (1996): 267-79

Harris, Trudier. Exorcising Blackness. Bloomington: Indiana UP, 1984.

Scarry, Elaine. The Body in Pain. Oxford: Oxford UP, 1985.

Walker, Margaret. Richard Wright: Daemonic Genius. New York: Warner, 1988.

West, Cornel. "Identity: A Matter of Life and Death." Prophetic Reflections: Notes on Race and Power in America. Monroe: Common Courage P. 1993.

Wright, Richard. "Between the World and Me." Partisan Review 2 (July-Aug. 1935): 18-19.

—. The Long Dream. 1958. New York: Harper, 1987.

—. Native Son. 1940. New York: Penguin, 1972.

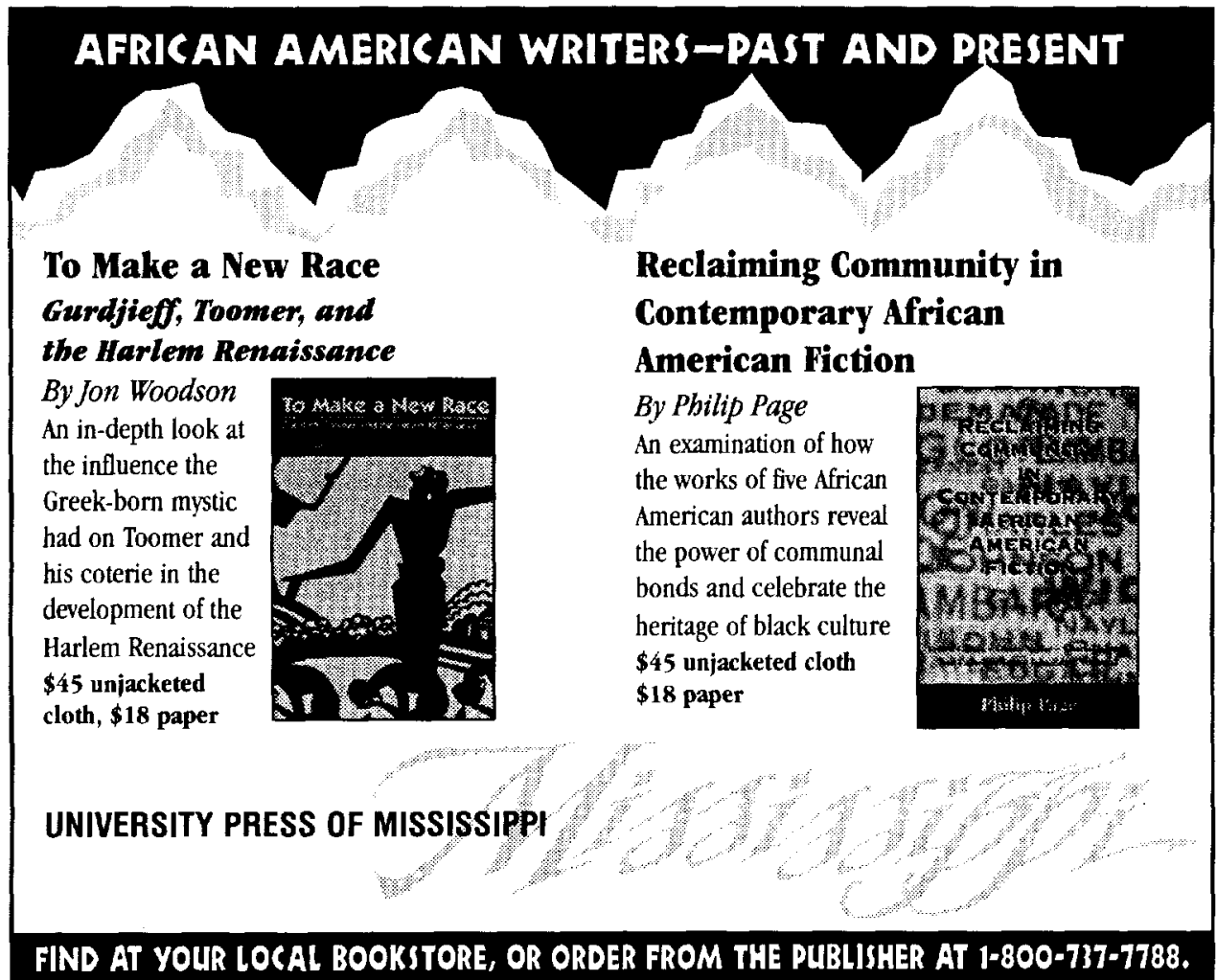

